\title{
The Quest for Feasibility of Second Classroom Construction in College Students' Dormitory Area
}

\author{
Haojun Dong ${ }^{1 *}$ \\ ${ }^{1}$ Economics and Management Collega, Zhaoqing University, Zhaoqing, Guangdong,526061, China \\ *Corresponding author. Email: donghaojun2791@qq.com
}

\begin{abstract}
Though problems exist in current construction of extracurricular activities in college students' living quarters, such as backward ideas, inadequate teaching hardware facilities, lacking relevant policy guarantee measurements and less support from the school education system, to develop the second classroom in students' dormitories is still of great necessity and feasibility. For instance, we can optimize the second classroom construction through constructing the second classroom system and improving the curriculum system construction, setting up rewards to encourage college students' participation in extracurricular activities, perfecting the evaluation and feedback system of the outcome, focusing attention on students' ideological guidance, providing special funds and some event space to carry out activities. In addition, there are also other significant approaches like forming a professional management team, assembling some high-quality teaching staffs and promoting the events with multiple ways.
\end{abstract}

Keywords: colleges and universities, students' dormitory area, the second classroom, the first classroom, feasibility

\section{INTRODUCTION}

Higher education in China has achieved rapid development in the past few years for the educational spirit keep pace with the times and the developing of traditional students' management system as well as the talents training mode. Meanwhile,some students' living quarters in colleges have gradually served as the important fronts for educating the undergraduates and performed a more vital role in their daily management and educational work towards students.

The second classroom is the extracurricular activities besides the main courses involved in the normal teaching plans, which also part of the school education ${ }^{[1]}$. The second classroom is different from the first ${ }^{[2-3]}$, the former is the major method for developing students' non-intelligence abilities such as shaping personality, edifying sentiment, developing emotional quotation and motivating the individual potential, etc. And the latter focus more on the theoretical study and students' intellectual development. However, the educational work of extracurricular classes is the effective supplement of the main one involved in college education, it can not only boost the undergraduates' all-round development, but also improve their competitiveness in the community. Thus, the impact of the second classroom is rather special compared to the first since it has played an essential part in university education system without any substitutions now.

This thesis will discuss the feasibility of second classroom construction in college students' living quarters by considering its critical role in students' growth course and how significant it is to implement this teaching project.

2.The Status of Second Classroom
Construction in College Students, Dormitory
Area

\subsection{Extracurricular Activities only Offered in Few Colleges}

Fewer domestic universities have provided special event space for second classroom activities in college students' dormitory area. Instead, most of them regard students' living place as noting more but a rest lounge. Therefore, we still shoulder heavy responsibilities toward spreading awareness of second classroom development.

\subsection{Most Students are Willing to Take Participate in Second Classroom Activities Held in Their Living Places}

The collegiate system is usually based on the living community, however, not all colleges and universities share the same way to reform the conventional rest serve. And the basic mode to implement is setting up a specialized activity center in dormitories as the place support for holding extracurricular activities. Taking Zhaoqing University for instance, there are five different living quarters: Houde College, Mingzhi College, Boxue College, Lixing College and Lanhui College were established from 2009 to the present. Meanwhile, a series 
out the second classroom teaching mode reform in such situation. in these colleges. Among them, students are active in those special events provided by the learning platform in Houde College such as the annual talks, exchange programs, stage play, dancing skills, guitar playing and radio activities.

\subsection{Extracurricular Activities Help to Improve Students' Comprehensive Capacity}

The college students' integrative abilities are closely bound up with their social competitiveness. However, in order to enhance these two abilities, they need to target the second classroom as a self-training platform and active in the extracurricular activities such as public service, innovative and entrepreneurial practice as well as artistic, cultural and sports activities to enrich their practical experience, expand the knowledge, improve the cultural awareness and reach themselves prefect.

\section{THE EXISTING PROBLEMS OF SECOND CLASSROOM CONSTRUCTION IN STUDENTS' DORMITORIES IN UNIVERSITIES}

\subsection{Backward Concepts Lead to Neglect the Importance of Second Classroom Construction in Students' Living Quarters}

Some instructional leaders in universities are not optimistic about the importance of students' dormitory construction and they insist an old-fashioned conviction that students' dormitory area only provides one single rest function, which may not be the prefect spot for holding extracurricular activities. Therefore, they are inclined to overlook its vital role in undergraduate ideological and political education, and they pay less attention to develop its advance towards students' comprehensive competence promotion and integrated development.

\subsection{Lacking Conditions to Develop the Second Classroom with Inadequate Teaching Hardware Facilities}

In recent years, students' living conditions and environmental amenity are highly valued in colleges and universities. Meanwhile, students' living environment and life quality have been led to significant improvement and achieve high satisfaction after taking a rang of measures: renovate the old dormitory buildings, build up new apartments, strengthen the hardware construction including to install air-conditioners in dormitory areas. But only few of these colleges are able to provide the dormitory hardware facilities with student-centered design and rational layout while most of them even hard to set up specialized event venues with limited space. They lack of conditions to carry

\subsection{Low Attention on Second Classroom Construction under Less Policy Support or Institutional Guarantee}

The relative policy support is the guiding thought of constructing extracurricular activities and it works as the direction, method and pattern that guides us to follow out the educational work in a new period. While the institutional guarantee serves as the logistics support which ensures all work process smoothly. Nevertheless, with the affect of traditional thoughts, to carry out the second classroom in college dormitory area still face challenges of lacking policy support and institutional guarantee. For instance, the facility construction associated with the second classroom have only been involved in the proposal of students' living quarters construction in few colleges and universities, but even worse, some of them fail to establish special funds to organize extracurricular activities in their dormitory area. In addition, there is also an overlook of systemic measures implements which leads in less attention on the curriculum content and course credit development of the second classroom.

\section{THE NECESSITY OF SECOND CLASSROOM CONSTRUCTION IN COLLEGE STUDENTS' LIVING QUARTERS}

\subsection{The Necessary Cause of Conducting Students' Ideological and Political Work in Dormitories}

The National conference on ideological and political work in universities which held on $7^{\text {th }}$ December,2016 in Beijing stressed the need to implement the ideology and political education work throughout the whole teaching process in every colleges and universities, so as to realize the thorough and all-round education. Moreover, students' dormitory area serves as an important place for students to join learning and living activities, is also a crucial front for high institutes' education and teaching work as well as an important premise to reach thorough and all-round education completion.

Conducting student's ideological and political work in college students' living quarters has become a research hotspot for years and a growing number of institutes give priority to develop this educational model. The research on it aims to lead students to set up the correct thoughts and advance their overall development by holding series of ideological and political-related activities in students' apartments with the concept of the second classroom. 
colleges and universities included Amoy University and East China Normal University together to discuss the collegiate personnel training mode innovation. Meanwhile, the second classroom construction in dormitory area also gets theoretical support and accumulates much experience under this new personal training mode.

\section{THE FEASIBILITY OF SECOND CLASSROOM CONSTRUCTIONINCOLLEGESTUDENTS' DORMINOTRY AREA} second classroom development to improve college students' synthetic quality and help to educate more talented students with all-round development of moral, intellectual, physical, aesthetics and labor is the inevitable trend of the times.

\subsection{Students' Real Appeal}

As the impact of traditional ideas, most dormitory area in colleges are inclined to follow a stepwise management system. This mode reflects in students' affairs office outranks the dormitory management center while the life teachers or dorm supervisors should follow the orders given by the dormitory management center. In addition, the school counselors from secondary colleges work as assistants to support the management. Under this mode, a safe living environment for students is created. Nevertheless, university students' views on communal culture have changed a lot in the new era. The living quarters in school are not just need to be safe and comfortable for them, but should also have the functions of quality living communities and help with their integrated capability promotion. Besides, the modern college students wish the dormitory area where they live could transform its single rest function to diversified functions, in that, they are able to participate in various activities and enhance their comprehensive abilities include self-organizing ability, communication ability, planning capacity and executive capability.

\subsection{The Inspiration of the New Personnel Training Mode}

With the extension of collegiate system reform across the nation at present, more and more colleges and universities such as Shanghai Fudan University, Xi'an Jiaotong University, East China Normal University and Zhaoqing University are inclined to imitate this system and cultivate talents though holding a series of extracurricular activities in their dormitory area. Meanwhile, the collegiate system has grown steadily and become stronger for the past few years with the establishment of the Collegiate School League which was launched in 2014 with seven universities engaged: Fudan University, Beijing University of Aeronautics and Astronautics,Xi'an Jiaotong University, etc. And on $5^{\text {th }}$ December of that year, the league convened a meeting of Research on Collegiate System with members from eighteen

\subsection{Students Show Higher Enthusiasm while the Extracurricular Activities are Concentrated in One Area}

Usually the extracurricular activities are holding in scattered places such as the student center, academic exchange center, playground, sports field, basketball court, soccer field or classroom, etc. Under this situation, students are inclined to give several excuses for themselves to evade their participation in second classroom events. The reasons could be "Long distance to the site of activity,I'd rather stay at dorm and read my books.", "It's quite far to walk there, I think I'll just learn online.","There's no need to go that far for the weather is too cold or too hot. Let's wait for the next chance when the weather is better."...But if we can set up a specialized event space in students' living quarters where various activities are concentrated, and that they may show higher enthusiasm to join in.

\subsection{Information about Second Classroom Activities Spread Fast and Easy to Attract Students' High Attention}

The school dormitory area is where students gathered, therefore, to put up bulletin boards, establish the WeChat official account and build the community website in dormitories make information about extracurricular events handling much faster for students. These measures also provide enough information for the students to keep an eye on the dormitory dynamic, follow the progress and learn about the effect of activities, and all these finally lead to their high concerns on the activities held in dormitories.

\subsection{Abundant Extracurricular Activities can Motivate the Students to Study}

The second classroom events holding in the undergraduates' dormitory area could be various types with rich content to arouse students' interest in study such as scientific academic lectures, scientific and 
and able to enhance their integrative competence as well as promote the development soundly and thoroughly. Whereas, one thing need to note is that the extracurriculum should be distinct from the traditional classroom teaching. The first classroom focus on students' intelligence, specialty foundation and professional skill development while the second classroom attach importance to develop their non-intellectual factors and overall capability. The curriculum designed involves moral shape course, etiquette lesson, interpersonal communication course and speech class as well as some activities like puzzle games and quality expansion. to carry out targeted extracurricular activities which conform students' practical demands, rise their interests, and meet individual requirements.

\subsection{The Second Classroom Activities Can Strengthen Students' Communication and Make Them Feel at Home}

University students in this modern society highly value and pursue spiritual satisfaction. To follow out more extracurricular events in their living quarters is to build bridges and help once strangers make friends and talk with each other.

\section{THECONSTRUCTIONPATHOFHOLDINGSECOND CLASSROOM ACTIVITIES IN COLLEGE STUDENTS' DORMITORIES}

\subsection{Break the Limit of Tradition and Construct a Second Classroom System in Dormitories}

Colleges and universities should lay emphasis on an unified thought that the credit system of the second classroom is different from the normal credit system of required courses, optional courses and general-knowledge courses while developing talent students cultivation program. However, the students could not graduate unless they were the active participants of extracurricular activities held in their dormitory area and already got adequate credits under the conditions of having required numbers of participation and achieved good effectiveness during college years. Moreover, constructing credit system of the second classroom can arouse undergraduates' awareness to perform active engagement and realize self-improvement.

\subsection{Improve the Curriculum System Construction and Provide Well-planned Course Content}

According to the previous investigation results from students' dormitory area, teachers could plan the course of the second classroom, optimize it to be a more complete curriculum that meets college students' practical demands

\subsection{Set Up Rewards to Encourage College Students' Participation in Extracurricular Events}

To motivate the undergraduates to play an active part in second classroom events, we should bring second classroom evaluation into comprehensive assessment system and offer some credits according to their performance. Moreover, the extracurricular practice can also be included in university social practice system, and each requested practice will be awarded 0.2 point However, teachers and active stuffs should register the participants' information carefully and award the Top Ten Students at the end of each semester.

\subsection{Perfect the Evaluation and Feedback System of the Outcome to Improve Students' Performance in Second Classroom}

To perfect the evaluation and feedback system of second classroom activities, some methods like questionnaire surveys, personal interviews and field investigations can be taken to collect students' suggestions after the event. We can learn from these data and evaluate the effectiveness of those activities, adjust the content and activity form to improve the teaching efficiency according to the feedback.

\subsection{Focus attention on Ideological Guidance and Propose Students' Wide Participation}

During the preparatory phrase of the second classroom construction, we educators need to arouse students' awareness of being active in participation of extracurricular activities through taking publicity measures such as to sent the leaflets, put up posters, hang the banners and so on. Besides, we can also organize topic class meetings to introduce the significance of second classroom construction, related curriculum and course contents in details. 


\subsection{Provide Special Funds to Ensure Second Classroom Construction Work Move Smoothly}

College and universities need to take into full consideration about the practical demand of organizing extracurricular events and provide special funds for them while making school budget. They can give support to the extracurricular hardware construction and improve the class quality, organize the teaching stuffs to do representative study of the second classroom at the regular intervals, encourage teachers to research theory and practice on the second classroom and set up specialized bonus fund to award students who are active participants.

\subsection{Create Conditions and Provide Some Event Space to Organize Extracurricular Activities.}

Lack of event space to organize extracurricular activities is the main challenge for short term. To solve this problem with existing condition, we could work in these two aspects: Firstly, to set up an activity center and renovate students' dormitory area according to the different types of second class activities. Secondly, to expand more public space in right place to meet the space requirements through doing the site plan and needs survey.

\subsection{Form a Professional Management Team to Achieve Specialized Management}

To ensure all the teaching process of the second classroom move smoothly, it is of necessity to form a professional management team to achieve specialized management. This team will contribute to improve the extracurricular construction work includes curricular arrangement, course and student management, information statistics, learning assessment, space resource allocation, grounds maintenance, publicity campaign, etc.

\subsection{Assemble Some High-quality Teaching Staffs to Improve Training Effectiveness}

In order to provide quality courses, make certain training effectiveness and promote students' growth and development,we are supposed to assemble some high-quality teaching staffs who are responsible, professional and able to teach well with good reputation according to different classroom types and course contents.

\subsection{Promote Extracurricular Activities in Multiple Ways and Extend the Publicity Effect}

we can promote second classroom activities in multiple ways to create a favorable atmosphere of public opinion towards second classroom events and arouse more students' attention on these activities. Several methods could be taken: put up bulletin boards to release the extracurriculum information in time, set up a WeChat official account to regularly post activity information and build the dormitory official website to update the news about second classroom process.

\section{CONCLUSION}

In short, as the time went by and modern society makes continuous progress while the college students improve their learning thoughts, students' dormitory area can not only stay a single rest function, but need to be the important fronts for students to promote their comprehensive abilities. We educators are supposed to break the tie of the old-fashioned thoughts, transform the conventional rest area into a personnel training cente, carry forward undergraduates' quality upgrade project and fully improve their all-round ability with the combination of the dormitory culture and second classroom construction.

\section{REFERENCES}

[1]Qiaoyin Peng, Xianguxun Xie. Second Treatise on the Relationship between the Second Classroom and the First Classroom[J]. The Party Building and Ideological Education in Schools,2011,5(14):45-46.

[2]Qi Liu. Research on the Second Classroom Construction in Colleges and Universities[J]. Education and Vocation,2014,(06):41-42.

[3]Liyuan Zhang,Kaisheng Zhou, Qinglan Qian, etc. Discussion on the Construction of the Second Classroom in Application Oriented Universities[J]. Guangdong Chemical Industry,2016,43(10):252. 